\title{
Effect of Different Dialysis Methods on Cellular Immunity Function of Maintenance Haemodialysis Patients
}

\author{
L Xing
}

\begin{abstract}
Background: The study of the effect of different dialysis methods on cellular immune function of maintenance haemodialysis (MHD) patients should provide theoretical support for deciding on the best method of blood purification that effectively improves cellular immune function of haemodialysis patients.

Subjects and Method: Sixty MHD patients were randomly divided into three groups that respectively received treatment of haemodialysis (HD), high flux haemodialysis (HFHD) and haemodiafiltration (HDF). Peripheral blood T lymphocyte subsets [CD4+, CD8+, CD25+ (mIL-2R) and CD4+/CD8+ ratio] and serum interleukin (IL)-2 and soluble IL-2 receptor (sIL-2R) levels were detected before dialysis and 4 , 24 and 48 hours after dialysis in all cases.

Results: Compared with the HD group, CD4+ and CD25+ cells, CD4+/CD8+ ratio and IL-2 level increased but sIL-2R level decreased in the HFHD and HDF groups at four hours without statistical significance $(p>0.05)$ and at 24 and 48 hours after dialysis with statistical significance $(\mathrm{p}<0.05)$, while $C D 8+$ cells had no change after dialysis $(\mathrm{p}>0.05)$. Compared with the HFHD group, CD4+ and CD25+ cells, CD4+/CD8+ ratio, and IL-2 level increased but sIL-2R level decreased in the HDF group at four and 24 hours without statistical significance $(\mathrm{p}>0.05)$ and at 48 hours after dialysis with statistical significance $(\mathrm{p}<0.05)$, while CD8+ cells had no change after dialysis $(\mathrm{p}>0.05)$.

Conclusion: The results indicate that HD can briefly improve the cellular immune function of MHD patients, while HDF and HFHD can improve it continuously, with HDF having the best effect.
\end{abstract}

Keywords: Cellular immunity, haemodiafiltration, haemodialysis, high flux haemodialysis, maintenance haemodialysis

\section{Efecto de los Diferentes Métodos de Diálisis sobre la Función de la Inmunidad Celular de Pacientes Sometidos a Hemodiálisis de Mantenimiento}

\author{
L Xing
}

\begin{abstract}
RESUMEN
Antecedentes: El estudio del efecto de los diferentes métodos de diálisis sobre la función de la inmunidad celular de pacientes sometidos a hemodiálisis de mantenimiento (HDM) debe proporcionar apoyo teórico a la hora de decidir el mejor método de purificación de la sangre que efectivamente mejore la función celular inmune de los pacientes de hemodiálisis.

Sujetos y Método: Sesenta pacientes de HDM fueron divididos aleatoriamente en tres grupos que respectivamente recibieron tratamiento de hemodiálisis (HD), hemodiálisis de alto flujo (HDAF) y hemodiafiltración $(H D F)$. Los subconjuntos de linfocitos T de sangre periférica [ratio $C D 4^{+}, C D 8^{+}, C D 25^{+}$ (mIL-2R) y $C D 4^{+} / C D 8^{+}$y los niveles séricos de (IL)-2 y sIL-2R fueron detectados antes de la diálisis, y 4, 24 y 48 horas después de la diálisis en todos los casos.

Resultados: En comparación con el grupo $H D$, las células $C D 4^{+}$y $C D 25^{+}$, la relación $C D 4^{+} / C D 8^{+}$y el nivel de IL-2 aumentaron, pero el nivel de sIL-2R se redujo en los grupos HDAF y HDF a las cuatro horas sin significación estadística ( $>$ > 0.05), y a las 24 y 48 horas después de la diálisis con significación estadística ( $\mathrm{p}<0.05)$, mientras que las células $C D 8^{+}$no tuvieron ningún cambio después de la diálisis ( $\mathrm{p}$ $>0.05)$. En comparación con el grupo HDAF, las células $C D 4^{+}$y $C D 25^{+}$, la relación $C D 4^{+} / C D 8^{+}$y el nivel IL-2 aumentaron, pero el nivel de sIL-2R disminuyó en el grupo HDF a las cuatro y las 24 horas sin sig-
\end{abstract}

From: Blood Purification Room, People's Hospital of Zhengzhou, Zhengzhou 450003, China.
Correspondence: Dr Li Xing, Blood Purification Room, People's Hospital of Zhengzhou, Zhengzhou 450003, China. E-mail: xingli5y@163.com 
nificación estadística ( $\mathrm{p}>0.05)$, y a las 48 horas después de la diálisis con significación estadística (p $<0.05)$, mientras que las células CD8 $8^{+}$no tuvieron ningún cambio después de la diálisis ( $\mathrm{p}>0.05$ ).

Conclusión: Los resultados indican que la HD puede mejorar brevemente la función celular inmune de los pacientes de HDM, mientras que HDF y HDAF pueden mejorarla continuamente, teniendo HDF el mejor efecto.

Palabras claves: Inmunidad celular, hemodiafiltración, hemodiálisis, hemodiálisis de alto flujo, hemodiálisis de mantenimiento

West Indian Med J 2015; 64 (5): 500

\section{INTRODUCTION}

Although the mortality of patients on dialysis has declined significantly, infection is still the second leading cause of death after cardiovascular disease (1). High infection rates in chronic end-stage renal failure patients exist in those with immunodeficiency, delayed hypersensitivity reaction to antigens, including vaccination and T-cell dependent antigens such as influenza virus and hepatitis B virus, and compromised immune response. Clinically, uraemic patients have complications such as autoimmune diseases, increased incidence of cancers and the combination of bacterial and viral infections.

Many studies suggest that chronic inflammation is a key factor in maintenance haemodialysis (MHD) patients leading to malnutrition, blood dyscrasia and vascular lesions. These syndromes of dialysis can cause high morbidity and mortality (2). Uraemic toxins can cause an immune system disorder which results in a micro inflammatory state and haemodialysis itself can heighten the inflammatory state. The main causes of inflammation are biological incompatibility of dialysis membrane, bacterial contamination of dialysate and acetate dialysate, among others (3).

Increased production of reactive oxygen species can be induced by chronic inflammation in long-term dialysis uraemia patients and not be effectively balanced by the antioxidation system. The state of oxidative stress that is induced ultimately will intensify the dialysis syndromes. The state of chronic micro-inflammation in long-term dialysis patients is mainly caused by two factors: immune deficiency and dialysis. In haemodialysis patients, a series of complex immune responses can be produced, such as complement activation (4-8), monocyte activation (9-12), synthesis and release of cytokines (13-18), oxidative stress (19-21), carbon oxygen radical generation (22-23) and nitric oxide production (24).

Current studies show that the frequent high incidence of bacterial infection and tumour in MHD patients is related to immune function disorder, which mainly manifests with low $\mathrm{T}$ lymphocytes and normal humoral immune function. T lymphocytes maintain the balance of the immune system by the mutual restriction of T helper cells (Th/CD4) and T suppressor cells (Ts/CD8) and the cooperation with other immune cells. Blood purification is the main measures of treatment of endstage renal disease (ESRD), and the common clinical methods of blood purification mainly include haemodialysis (HD), high flux haemodialysis (HFHD) and haemodiafiltration (HDF).
The effects of different blood purification methods on cellular immune function of MHD patients have been rarely reported.

\section{SUBJECTS AND METHODS}

Sixty patients on maintenance haemodialysis were chosen between March and August 2012, and were randomly divided into three groups that respectively received treatment of haemodialysis (HD group), high flux haemodialysis (HFHD group) and haemodiafiltration (HDF group). Twenty cases of healthy volunteers were chosen as the healthy control group (N Group). The inclusion criteria for the maintenance haemodialysis patients were serum creatinine ( $\mathrm{SCr}$ ) more than 707 $\mu \mathrm{mol} \cdot \mathrm{L}^{-1}$ or creatinine clearance rate $(\mathrm{CCr})$ less than 10 $\min \cdot \mathrm{mL}^{-1}$ and the dialysis duration was more than three months. The exclusion criteria for maintenance haemodialysis patients were those with diseases such as diabetic nephropathy and lupus nephritis which induce abnormal cellular immunity, tumour, infection or heart failure in the last three months, malnutrition, blood transfusion in the last month, use of antibiotics and immunosuppressive agents.

\section{Collection of clinical data}

Maintenance haemodialysis patients comprised 29 cases of chronic glomerulonephritis (cGN), 18 cases of benign arteriolar nephrosclerosis (BANS), five cases of autosomal dominant polycystic kidney disease (ADPKD), four cases of obstructive nephropathy $(\mathrm{ON})$ and four cases of chronic interstitial nephritis (CIN).

Clinical data including name, gender, age, body mass index (BMI), co-morbid conditions, course of ESRD, duration of dialysis, systolic and diastolic blood pressure (SBP/DBP), heart rate (HR), routine blood tests, liver function, kidney function, spKt/V, SI, total iron-binding capacity (TIBC), erythropoietin (EPO) doses, chest X-ray and ultrasonic cardiogram of regular MHD patients are seen in Table 1.

Maintenance haemodialysis patients were randomly divided into three groups, with 20 cases in each group: HD group: 13 males and seven females, aged from 26 to 79 years old, average age $52.65 \pm 16.82$ years; HFHD group: 12 males and eight females, aged from 21 to 75 years old, average age $51.25 \pm 15.35$ years; HDF group: 11 males and nine females, aged from 22 to 76 years old; average age $53.10 \pm 17.19$ years old. The three groups of dialysis patients were dialysed three times a week, each time for four hours. There was no signifi- 
cant difference in gender and age among the three groups $(p>$ 0.05; Table 1).
$4 \mathrm{~mL}$ of venous blood heparin inspection. In the morning, fasting venous blood samples from the healthy control group were anticoagulated with heparin $4 \mathrm{~mL}$. FACSCalibur flow cy-

Table 1: Baseline clinical characteristics of three groups of MHD patients

\begin{tabular}{|c|c|c|c|c|c|c|}
\hline \multirow{2}{*}{$\begin{array}{l}\text { Baseline clinical } \\
\text { characteristics }\end{array}$} & \multirow{2}{*}{$\begin{array}{l}\text { HD group } \\
(n=20)\end{array}$} & \multirow{2}{*}{$\begin{array}{l}\text { HFHD group } \\
\quad(n=20)\end{array}$} & \multirow{2}{*}{$\begin{array}{l}\text { HDF group } \\
\quad(n=20)\end{array}$} & \multicolumn{3}{|c|}{$p$} \\
\hline & & & & $\begin{array}{c}\text { HD } \\
\text { vs HFHD }\end{array}$ & $\begin{array}{c}\text { HD } \\
v s \mathrm{HDF}\end{array}$ & $\begin{array}{c}\text { HFHD vs } \\
\text { HDF }\end{array}$ \\
\hline Male/female & $13 / 7$ & $12 / 8$ & $11 / 9$ & $1.000^{\mathrm{b}}$ & $1.000^{\mathrm{b}}$ & $1.000^{\mathrm{b}}$ \\
\hline Age (years) & $52.65 \pm 16.82$ & $51.25 \pm 15.35$ & $53.10 \pm 17.19$ & $0.5296^{\mathrm{a}}$ & $0.5387^{\mathrm{a}}$ & $0.4398^{\mathrm{a}}$ \\
\hline \multicolumn{7}{|c|}{ Diseases caused by renal failure $(\%)$} \\
\hline $\mathrm{cGN}$ & $9(45 \%)$ & $10(50 \%)$ & $10(50 \%)$ & $0.6767^{\mathrm{b}}$ & $0.6767^{\mathrm{b}}$ & $1.000^{\mathrm{b}}$ \\
\hline BANS & $6(30 \%)$ & $7(35 \%)$ & $5(25 \%)$ & $1.000^{\mathrm{b}}$ & $1.000^{\mathrm{b}}$ & $1.000^{\mathrm{b}}$ \\
\hline ADPKD & $2(10 \%)$ & $1(5 \%)$ & $2(10 \%)$ & $1.000^{\mathrm{b}}$ & $1.000^{\mathrm{b}}$ & $1.000^{\mathrm{b}}$ \\
\hline ON & $1(5 \%)$ & $1(5 \%)$ & $2(10 \%)$ & $1.000^{\mathrm{b}}$ & $0.7398^{b}$ & $0.7546^{\mathrm{b}}$ \\
\hline CIN & $2(10 \%)$ & $1(5 \%)$ & $1(5 \%)$ & $0.7546^{\mathrm{b}}$ & $0.7546^{\mathrm{b}}$ & $1.000^{\mathrm{b}}$ \\
\hline \multicolumn{7}{|l|}{ Vascular access for dialysis (\%) } \\
\hline Arteriovenous fistula & $20(100 \%)$ & $20(100 \%)$ & $20(100 \%)$ & - & - & - \\
\hline BMI $\left(\mathrm{kg} \cdot \mathrm{m}^{-2}\right)$ & $23.3 \pm 1.4$ & $22.7 \pm 2.1$ & $22.9 \pm 3.1$ & $0.5834^{\mathrm{a}}$ & $0.5435^{\mathrm{a}}$ & $1.000^{\mathrm{a}}$ \\
\hline \multicolumn{7}{|l|}{ Complications (\%) } \\
\hline CAD & $4(20 \%)$ & $5(25 \%)$ & $6(30 \%)$ & $0.8765^{\mathrm{b}}$ & $1.000^{\mathrm{b}}$ & $1.000^{\mathrm{b}}$ \\
\hline Congestive heart failure & $7(35 \%)$ & $8(40 \%)$ & $6(30 \%)$ & $0.6234^{\mathrm{b}}$ & $0.6545^{\mathrm{b}}$ & $0.5436^{\mathrm{b}}$ \\
\hline Peripheral vascular disease & e $2(10 \%)$ & $1(5 \%)$ & $2(10 \%)$ & $0.5689^{b}$ & $1.0000^{\mathrm{b}}$ & $0.5689^{\mathrm{b}}$ \\
\hline Stroke & $1(5 \%)$ & $2(10 \%)$ & $3(15 \%)$ & $0.6136^{\mathrm{b}}$ & $0.5103^{b}$ & $0.6547^{\mathrm{b}}$ \\
\hline COPD & $1(5 \%)$ & $1(5 \%)$ & $1(5 \%)$ & $1.000^{\mathrm{b}}$ & $1.000^{\mathrm{b}}$ & $1.000^{\mathrm{b}}$ \\
\hline \multicolumn{7}{|l|}{ Dialysis } \\
\hline duration (months) & $20.7 \pm 10.2$ & $24.9 \pm 11.1$ & $23.1 \pm 14.4$ & $0.0729^{\mathrm{a}}$ & $0.0987^{\mathrm{a}}$ & $0.2384^{\mathrm{a}}$ \\
\hline $\mathrm{SBP}(\mathrm{mmHg})$ & $153.8 \pm 47.2$ & $155.1 \pm 46.6$ & $154.3 \pm 44.9$ & $0.8675^{\mathrm{a}}$ & $0.8356^{\mathrm{a}}$ & $0.8765^{\mathrm{a}}$ \\
\hline $\mathrm{DBP}(\mathrm{mmHg})$ & $88.8 \pm 28.3$ & $87.3 \pm 28.9$ & $89.4 \pm 27.3$ & $0.6575^{\mathrm{a}}$ & $0.6228^{a}$ & $0.5436^{\mathrm{a}}$ \\
\hline \multicolumn{7}{|l|}{ Laboratory data } \\
\hline Albumin $\left(g \cdot \mathrm{dL}^{-1}\right)$ & $3.4 \pm 0.4$ & $3.5 \pm 0.5$ & $3.6 \pm 0.4$ & $0.3776^{\mathrm{a}}$ & $0.2578^{\mathrm{a}}$ & $0.3987^{\mathrm{a}}$ \\
\hline $\mathrm{Ca}^{2+}\left(\mathrm{mg} \cdot \mathrm{dL}^{-1}\right)$ & $8.5 \pm 0.6$ & $8.3 \pm 0.9$ & $8.4 \pm 0.8$ & $0.5098^{\mathrm{a}}$ & $0.5568^{\mathrm{a}}$ & $0.5378^{\mathrm{a}}$ \\
\hline $\mathrm{P}^{3+}\left(\mathrm{mg} \cdot \mathrm{dL}^{-1}\right)$ & $4.9 \pm 1.8$ & $4.7 \pm 1.6$ & $4.8 \pm 1.5$ & $0.6578^{\mathrm{a}}$ & $0.7089^{\mathrm{a}}$ & $0.7546^{\mathrm{a}}$ \\
\hline iPTH $\left(\mathrm{pg} \cdot \mathrm{dL}^{-1}\right)$ & $259.78 \pm 160.09$ & $276.93 \pm 155.28$ & $262.66 \pm 153.85$ & $0.4001^{\mathrm{a}}$ & $0.4757^{\mathrm{a}}$ & $0.4756^{\mathrm{a}}$ \\
\hline $\mathrm{Hb}\left(\mathrm{g} \cdot \mathrm{L}^{-1}\right)$ & $86.3 \pm 16.4$ & $83.5 \pm 17.9$ & $84.9 \pm 18.3$ & $0.4327^{\mathrm{a}}$ & $0.4676^{\mathrm{a}}$ & $0.6567^{\mathrm{a}}$ \\
\hline $\mathrm{spKt} / \mathrm{V}$ & $1.49 \pm 0.20$ & $1.47 \pm 0.19$ & $1.46 \pm 0.17$ & $0.3987^{\mathrm{a}}$ & $0.4345^{\mathrm{a}}$ & $0.5546^{\mathrm{a}}$ \\
\hline
\end{tabular}

a two-sample $t$-test; ${ }^{\mathrm{b}}$ Fisher's exact test

cGN: chronic glomerulonephritis; BANS: benign arteriolar nephrosclerosis; ADPKD: autosomal dominant polycystic kidney disease; ON:

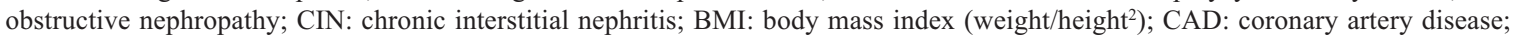
COPD: chronic obstructive pulmonary disease; SBP: systolic blood pressure; DBP: diastolic blood pressure; $\mathrm{Ca}^{2+}$ : serum calcium; $\mathrm{P}^{3+}$ : serum phosphorus; iPTH: immunoreactive parathyroid hormone; Hb: haemoglobin; spKt/V(3): $-\mathrm{Ln}(\mathrm{R}-0.008 \times \mathrm{T})+(4-3.5 \times \mathrm{R}) \times \mathrm{UF} / \mathrm{BW}$, where R: the ratio between urea concentration after dialysis and before dialysis; T: dialysis time; UF: weight loss value of patient after dialysis; BW: patient's weight after dialysis; Ln: natural logarithm

\section{Dialysis method}

The haemodialysis machines were German Fresenius production of 4008, 4008S. The HD group used Braun LOPS15 dialysis, blood flow rate of $200 \sim 250 \mathrm{~mL} \cdot \mathrm{min}^{-1}$, dialysate flow rate of $500 \mathrm{~mL} \cdot \mathrm{min}^{-1}$. The other two groups used Braun HIP 15 dialyser, with blood flow rate from 230 to $250 \mathrm{~mL} \cdot \mathrm{min}^{-1}$, dialysate flow rate of $500 \mathrm{~mL} \cdot \mathrm{min}^{-1}$. Post exchanging method was used for haemodiafiltration and the amount of fluid replacement was $18 \sim 20 \mathrm{~L}$. All patients were treated with bicarbonate dialysis and polysulfone dialysers. Dialysers were disposable.

\section{Detection index and method}

Maintenance haemodialysis patients were on dialysis before (T0) elbow vein blood dialysis, four hours (T4 h) after vein dialysis ended and 24 hours (T24 h) and 48 hours (T48 h) after tometer (BD Biosciences, USA) was used for the detection of T lymphocyte subsets $\left(\mathrm{CD} 4^{+}, \mathrm{CD} 8^{+}, \mathrm{CD} 25^{+}\right.$[membrane interleukin factor receptor $2-\mathrm{mIL}-2 \mathrm{R}]$ and $\mathrm{CD} 4^{+} / \mathrm{CD}^{+}$ratio) which were calculated. Enzyme-linked immunosorbent assay (ELISA) method was used to detect the value of interleukin (IL)-2 and soluble interleukin 2 receptor (sIL-2R).

\section{Data analysis}

The experimental data were analysed with SPSS 13.0 software and results are listed as mean $\pm \mathrm{SD}$. Repetitive measurement and analysis of variance were performed for the comparison of two groups. The difference between two means was compared with $q$ test. The difference was statistically significant when $p<0.05$. 


\section{RESULTS}

\section{Changes in $\mathrm{T}$ lymphocyte subsets}

The amount of $\mathrm{CD}^{+}, \mathrm{CD}^{2} 5^{+}$and $\mathrm{CD}^{+} / \mathrm{CD}^{+}$in the $\mathrm{HD}$, HFHD and HDF groups was significantly decreased, and the difference was statistically significant ( $p<0.05$; Table 2$)$. The difference in amount of $\mathrm{CD}^{+}$was not statistically significant $(p>0.05$; Table 2). There was no significant difference in $\mathrm{CD}^{+}, \mathrm{CD}^{+}, \mathrm{CD} 25^{+}$and $\mathrm{CD} 4^{+} / \mathrm{CD}^{+}$among $\mathrm{HD}, \mathrm{HFHD}$ and HDF groups ( $p>0.05$; Table 2$)$. The amount of CD $4^{+}, \mathrm{CD} 25^{+}$ and $\mathrm{CD}^{+} / \mathrm{CD}^{+}$at four hours after dialysis in patients of the HD group increased compared with that before dialysis; the difference was statistically significant ( $p<0.05$; Table 2$)$, while the differences of these indices at 24 hours and 48 hours after dialysis and before dialysis were not statistically signifi- cant $(p>0.05$; Table 2$)$. The amount of $\mathrm{CD}^{+}$after dialysis compared with before dialysis at each time point was not statistically significant ( $p>0.05$; Table 2 ).

The amount of $\mathrm{CD}^{+}$and $\mathrm{CD} 25^{+}$cells and $\mathrm{CD} 4^{+} / \mathrm{CD}^{+}$ ratio in the HFHD and HDF groups at 4, 24 and 48 hours after dialysis compared with before dialysis increased; the difference was statistically significant ( $p<0.05$; Table 2$)$, while the amount of $\mathrm{CD}^{+}$cells had no change after dialysis $(p>0.05$; Table 2).

Compared with the $\mathrm{HD}$ group, $\mathrm{CD}^{+}$and $\mathrm{CD}^{2} 5^{+}$cells and $\mathrm{CD}^{+} / \mathrm{CD}^{+}$ratio increased in the HFHD and HDF groups at four hours without statistical significance $(p>0.05)$ and at 24 and 48 hours after dialysis with statistical significance $(p<$ 0.05; Table 2, Fig. 1A, C, D), while $\mathrm{CD}^{+}$cells had no change

Table 2: Changes of lymphocyte subsets in patients treated with different dialysis methods $(n=20$; mean $\pm \mathrm{SD})$

\begin{tabular}{lllllc}
\hline Group & Time (hours) & $\mathbf{C D}_{\mathbf{4}}{ }^{+} \mathbf{( \% )}$ & $\mathbf{C D}_{\mathbf{8}}{ }^{+} \mathbf{( \% )}$ & $\mathbf{C D}_{\mathbf{4}}{ }^{+} / \mathbf{C D}_{\mathbf{8}}{ }^{+}$ & $\begin{array}{c}\mathbf{C D}_{\mathbf{2 5}}{ }^{+} \\
\text {(mIL-2R) (\%) }\end{array}$ \\
\hline N group & T0 & $45.17 \pm 5.92$ & $29.72 \pm 5.79$ & $1.66 \pm 0.41$ & $26.21 \pm 6.71$ \\
& T0 & $31.59 \pm 4.98^{*}$ & $26.99 \pm 4.77$ & $1.20 \pm 0.33^{*}$ & $15.76 \pm 4.03^{*}$ \\
& T4 h & $39.74 \pm 5.91^{\#}$ & $29.74 \pm 5.36$ & $1.51 \pm 0.29^{\#}$ & $21.95 \pm 4.55^{\#}$ \\
& T24 h & $35.01 \pm 6.02$ & $27.88 \pm 4.91$ & $1.22 \pm 0.30$ & $16.33 \pm 4.55$ \\
& T48 h & $32.75 \pm 5.96$ & $28.32 \pm 5.02$ & $1.28 \pm 0.36$ & $14.47 \pm 4.96$ \\
HFHD group & T0 & $29.54 \pm 5.72^{*}$ & $26.67 \pm 5.99$ & $1.23 \pm 0.36^{*}$ & $13.56 \pm 3.94^{*}$ \\
& T4 h & $41.58 \pm 6.00^{\#}$ & $28.01 \pm 4.98$ & $1.54 \pm 0.29^{\#}$ & $26.46 \pm 4.99^{\#}$ \\
& T24 h & $39.06 \pm 6.33^{\# \Delta}$ & $27.94 \pm 5.76$ & $1.50 \pm 0.40^{\# \Delta}$ & $20.19 \pm 4.58^{\# \Delta}$ \\
& T48 h & $36.88 \pm 5.54^{\# \Delta}$ & $27.99 \pm 5.89$ & $1.43 \pm 0.29^{\# \Delta}$ & $19.26 \pm 4.11^{\# \Delta}$ \\
& T0 & $30.87 \pm 4.98^{*}$ & $28.11 \pm 5.28$ & $1.22 \pm 0.37^{*}$ & $14.39 \pm 4.47^{*}$ \\
& T4 h & $43.87 \pm 5.98^{\#}$ & $28.57 \pm 5.74$ & $1.60 \pm 0.30^{\#}$ & $25.78 \pm 4.29^{\#}$ \\
& T24 h & $40.62 \pm 5.28^{\# \Delta}$ & $28.62 \pm 5.58$ & $1.56 \pm 0.29^{\# \Delta}$ & $22.99 \pm 3.98^{\# \Delta}$ \\
& T48 h & $40.19 \pm 5.19^{\# \Delta \dagger}$ & $28.83 \pm 5.88$ & $1.54 \pm 0.31^{\# \Delta \dagger}$ & $21.93 \pm 4.55^{\# \Delta \dagger}$ \\
\hline
\end{tabular}

${ }^{\#}$ compared with T0, $p<0.05 ;{ }^{*}$ compared with $\mathrm{N}$ group, $p<0.05 ;{ }^{\Delta}$ compared with HD group, $p<0.05 ;{ }^{\dagger}$ compared with HFHD group, $p<0.05$.

$\mathrm{N}$ group: control group; HD: haemodialysis; HFHD: high flux haemodialysis; HDF: haemodiafiltration; mIL2R: membrane interleukin factor receptor 2
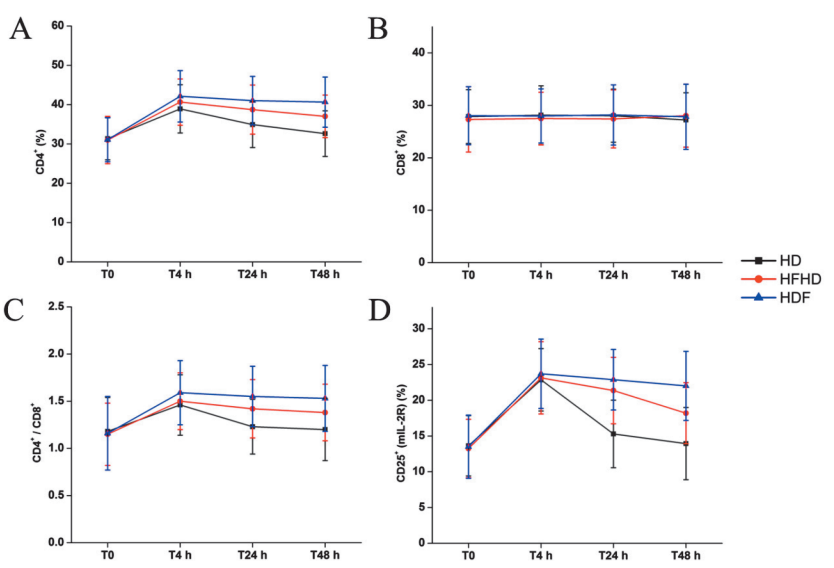

Fig. 1: Changes in lymphocyte subsets in patients treated with different dialysis methods.

HD: haemodialysis; HFHD: high flux haemodialysis; HDF: haemodiafiltration after dialysis ( $p>0.05$; Table 2, Fig. 1B). Compared with the HFHD group, $\mathrm{CD}^{+}$and $\mathrm{CD} 25^{+}$cells and $\mathrm{CD} 4^{+} / \mathrm{CD}^{+}$ratio increased in the HDF group at four and 24 hours without statistical significance $(p>0.05)$ and at 48 hours after dialysis with statistical significance ( $p<0.05$; Table 2, Fig. 1A, C, D), while $\mathrm{CD} 8^{+}$cells had no change after dialysis $(p>0.05$; Table 2, Fig. 1B).

\section{Changes in IL-2 and sIL-2R}

Interleukin-2 decreased significantly in patients in the HD, HFHD and HDF groups, compared with the normal control group, while sIL-2R increased significantly and the differences were statistically significant $(p<0.05$; Table 3$)$. There were no statistical differences in IL-2 and sIL-2R in patients of the three groups before dialysis.

The amount of IL-2 in the HD group after dialysis increased compared with that before dialysis, and the amount of sIL-2R decreased; the differences were statistically significant 
$(p<0.05)$, while the differences in these indices at 24 hours and 48 hours after dialysis and before dialysis were not statistically significant ( $p>0.05$; Table 3 , Fig. 2$)$.

The amount of IL-2 at 4, 24 and 48 hours after dialysis in the HFHD and HDF groups was higher than that before dialysis and the amount of sIL-2R was lower; these differences were statistically significant ( $p<0.05$; Table 3 , Fig. 2 ).

The amount of IL-2 at 4, 24 and 48 hours after dialysis in the HFHD and HDF groups was higher than that in the HD group and the amount of sIL-2R was lower. These differences at four hour after dialysis were not statistically significant $(p>$ 0.05 ), while these differences at 24 and 48 hours after dialysis were statistically significant ( $p<0.05$; Table 3, Fig. 2).

Table 3: Changes in IL-2 and sIL-2R in patients treated with different dialysis methods $(\mathrm{n}=20$; mean $\pm \mathrm{SD})$

\begin{tabular}{llcl}
\hline Group & Time (hours) & IL-2 $\left(\boldsymbol{\mu g} \cdot \mathbf{m L}^{-1}\right)$ & sIL-2R $\left(\mathbf{U} \cdot \mathbf{m L}^{-1}\right)$ \\
\hline N group & T0 & $41.99 \pm 9.54$ & $400.68 \pm 85.96$ \\
HD group & T0 & $17.88 \pm 4.76^{*}$ & $888.63 \pm 182.78^{*}$ \\
& T4 $\mathrm{h}$ & $22.02 \pm 5.37^{\#}$ & $655.71 \pm 111.98^{\#}$ \\
& T24 $\mathrm{h}$ & $18.67 \pm 4.99$ & $800.54 \pm 132.94$ \\
& T48 $\mathrm{h}$ & $17.98 \pm 5.00$ & $877.36 \pm 158.34$ \\
HFHD group & T0 & $18.36 \pm 4.76^{*}$ & $888.99 \pm 164.86^{*}$ \\
& T4 $\mathrm{h}$ & $22.98 \pm 4.93^{\#}$ & $654.09 \pm 133.84^{\#}$ \\
& T24 $\mathrm{h}$ & $22.76 \pm 4.67^{\# \Delta}$ & $682.37 \pm 144.79^{\# \Delta}$ \\
& T48 $\mathrm{h}$ & $21.04 \pm 6.01^{\# \Delta}$ & $745.67 \pm 130.00^{\# \Delta}$ \\
HDF group & T0 & $18.18 \pm 4.44^{*}$ & $900.72 \pm 200.35^{*}$ \\
& T4 $\mathrm{h}$ & $23.92 \pm 5.83^{\#}$ & $622.57 \pm 159.31^{\#}$ \\
& T24 $\mathrm{h}$ & $24.63 \pm 4.98^{\# \Delta}$ & $645.72 \pm 140.28^{\# \Delta}$ \\
& T48 $\mathrm{h}$ & $23.09 \pm 5.38^{\# \dagger}$ & $681.93 \pm 109.66^{\# \Delta \dagger}$ \\
\hline
\end{tabular}

"compared with T0, $p<0.05$; ${ }^{*}$ compared with n group, $p<0.05 ;{ }^{\Delta}$ compared with HD group, $p<0.05$; ${ }^{\dagger}$ compared with HFHD group, $p<0.05$

IL-2: interleukin-2; sIL-2R: soluble interleukin 2 receptor; N: normal control; HD: haemodialysis; HFHD: high flux haemodialysis; HDF: haemodiafiltration

The amount of IL-2 at 4, 24 and 48 hours after dialysis in the HDF group was higher than that in the HFHD group and the amount of sIL-2R was lower. These differences at four and 24 hours after dialysis were not statistically significant $(p>$ 0.05 ), while these differences at 48 hours after dialysis were statistically significant $(p<0.05$; Table 3 , Fig. 2$)$.
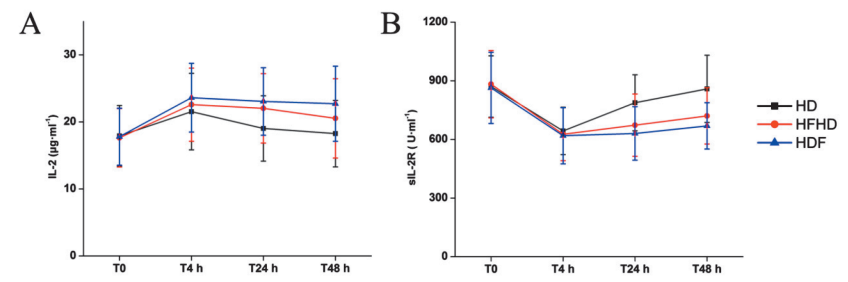

Fig. 2: Changes in IL-2 and sIL-2R in patients treated with different dialysis methods.

IL-2: interleukin-2; sIL-2R: soluble interleukin 2 receptor; HD: haemodialysis; HFHD: high flux haemodialysis; HDF: haemodiafiltration

\section{DISCUSSION}

Immune dysfunction in maintenance haemodialysis patients is thought to be due to the accumulation of uraemic toxin, the mechanical stimulation from dialysis blood pump, the bacterial pollution of dialysate and their metabolites (such as endotoxin or lipopolysaccharide fragment), the biological incompatibility of dialysis membrane, malnutrition etc, which affect the patients' survival rate and quality of life $(25,26)$.

Interleukin- 2 is secreted by $\mathrm{CD} 4^{+}$and enhances the activity of cytokines. The combination of IL-2 and IL-2R regulates proliferation and function of immune cells. Membrane interleukin factor receptor 2 was found on the surface of the cell membrane. The expression of mIL-2R $\left(\mathrm{CD} 25^{+}\right)$is a marker of activation of T lymphocytes, and sIL-2R is an immunosuppressive factor. In normal human serum, sIL-2R content is rare. When immune function is low, sIL-2R levels are significantly elevated, which is positively related to the illness $(27,28)$.

The research results showed that the MHD patients with cellular immune dysfunction showed significant reduction of $\mathrm{CD}^{+}$, no obvious change in $\mathrm{CD} 8^{+}$and decreased ratio of $\mathrm{CD} 4^{+} / \mathrm{CD}^{+}$compared with the normal control group. The corresponding changes in cytokines IL-2 and $\mathrm{mIL}-2 \mathrm{R}$ were significantly reduced and sIL-2R increased significantly more than that of normal people, which showed that cellular immune function in MHD patients was significantly inhibited compared with the normal control group. Maintenance haemodialysis patients received dialysis three times per week, with an interval of 48 hours, so the time point of our experimental design could reflect the changes in cellular immune function in these patients.

Haemodialysis mainly used the principle of diffusion, which is good for the removal of small molecules and water soluble toxins, but it is not good for the removal of other types, especially large molecular uraemic toxins. Currently, the toxins clearly known to inhibit immune cell activity include granulocyte inhibitory protein I (GIP-I), granulocyte inhibitory protein II (GIP-II), neutrophil degranulation inhibition of protein I (DIP-I), neutrophil degranulation inhibition of protein II (DIP-II) and the light chain of immunoglobulin protein, which all belong to high molecular weight uraemic toxins (25-29).

This study showed that $\mathrm{CD} 4^{+}, \mathrm{CD} 4^{+} / \mathrm{CD} 8^{+}, \mathrm{IL}-2$ and mIL-2R $\left(\mathrm{CD} 25^{+}\right)$increased and SIL-2R decreased at four hours after dialysis in the HD group, compared with T0. However, the above indices at 24 hours and 48 hours after dialysis had no significant difference compared with $\mathrm{T} 0$. This indicated that HD can temporarily improve cellular immune function in MHD patients, but after dialysis, with uraemic toxins again accumulating in the body and the influence of dialysis membrane biological incompatibility, cellular immune function gradually decreased after being maintained for a period of time. Therefore, single HD generally cannot improve the cellular immune function of patients. 
High flux haemodialysis with high flux dialyser, by convection, diffusion and absorption can remove small molecule toxins and some large molecule toxins (including low molecular protein). High flux haemodialysis simulates the principle of glomerular filtration, filters out a large amount of fluid from the blood on the basis of haemodialysis applying high pass through the filtration membrane, and inputs differential replacement fluid at the same time. In recent years, HFHD has been used in clinical treatments more and more widely.

Haemodiafiltration uses the principle of convection, diffusion and absorption, effectively removing toxins of small molecules and macromolecules. In the HDF machine, bacteria and macromolecule compounds produced by bacteria in the dialysis water can be entrapped by the filtering effect of internal $0.22 \mu \mathrm{m}$ filter and endotoxin and small molecule pyrogens can be intercepted by the absorption effect. The bacterial endotoxin in HDF haemodialysis water is reduced about $10^{6}$ times compared with conventional blood dialysis, but the amount of loss of protein in the dialysis process increases compared with the former two dialysis methods $(30,31)$.

The study by Kim et al found that HDF can better remove the toxins in the body of patients with uraemia, such as leptin and $\beta 2$-microspheres (32). Melero-Rubio et al compared the scavenging effect of conventional dialysis and HDF of nephropathy patients with the same type of homocysteine (Hcy) and found that the Hcy level was lower in the HDF group, which indicates the reduction of the incidence of cardiovascular disease risk (33). Hyodo et al observed the effect of haemodialysis and HDF on urine of patients with uraemia over a three-year follow-up and found that HDF can protect the residual renal function in MHD patients (34). Ledebo and Blankestijn (35) further compared the difference of clearance of vitamin B12, inulin and other high molecular toxin clearance by the different methods of blood purification, and different blood purification dialysis liquid bacteria, and the effect of bacteria and pyrogen on the body and concluded that online haemodiafiltration is the most effective and safest treatment method to remove toxins, compared with routine blood dialysis, high flux haemodialysis and traditional haemodiafiltration.

\section{CONCLUSION}

This study showed that $\mathrm{CD}^{+}, \mathrm{CD}^{+} / \mathrm{CD}^{+}, \mathrm{IL}-2$ and $\mathrm{mIL}-2 \mathrm{R}$ $\left(\mathrm{CD} 25^{+}\right)$increased and sIL-2R decreased in HFHD and HDF groups at 4, 24 and 48 hours after dialysis compared with that before dialysis, indicating that the cellular immune function of patients after dialysis can be improved to a certain extent, which is more obvious in the HDF group. This may result in a significantly higher clearance rate of macromolecular toxins in the HFHD and especially the HDF group, compared with the HD group. In addition, large quantities of sterile replacement fluid without pyrogen causing heat was generated online in the HDF group, so cellular immune function of patients in the HDF group improved more significantly than that in the HFHD group.
The goal of dialysis therapy is not only to remove water and solute to correct acid-base imbalance problem, but also to maintain normal immune function. Both HFHD and HDF can improve the cellular immune function of MHD patients, in order to reduce the incidence of infection and tumour, and improve their survival rate and quality of life. Thus, HFHD and HDF are worthy of further promotion in clinical treatments, especially HDF.

\section{REFERENCES}

1. Excerpts from United States Renal Data System 1999. Annual data report. Am J Kidney Dis 1999; 34 (Suppl): S1-S176.

2. Tsakiris D, Jones EHP, Briggs D, Elinder CG, Mehls O, Mendel S et al. Death within 90 days from starting renal replacement therapy in the ERAEDTA Registry between 1990 and 1992. Nephrol Dial Transplant 1999; 14: 2343-50.

3. Shoji T, Nishizawa Y. Effects of vitamin D on the cardiovascular system. Clin Calcium 2006; 16: 1107-14.

4. Acosta J, Hettings J, Flückiger R, Krumrei N, Goldfine A, Angarita L et al. Molecular basis for a link between complement and the vascular complications of diabetes. Proc Natl Acad Sci USA 2000; 97: 5450-5.

5. Panichi V, Miglio M, De Pietro S, Taccola D, Andreini B, Metelli MR et al. The link of biocompatibility to cytokine production. Kidney Int 2000; 58: S96-S103.

6, Lagrand WK, Cees A, Visser CA, Niessen HW, Verheugt FW, Wolbink GJ et al. C-reactive protein as a cardiovascular risk: more than an epiphenomenon? Circulation 1999; 100: 96-102.

7. Zoccali C, Tripepi G, Mallamaci F. Dissecting inflammation in ESRD: Do cytokines and C-reactive protein have a complementary prognostic value for mortality in dialysis patients? J Am Soc Nephrol 2006; 17 (Suppl 3): S169-S173.

8. Calvani M, Benatti P, Mancinelli A, D'Iddio S, Giordano V, Koverech A et al. Carnitine replacement in end-stage renal disease and hemodialysis. Ann NY Acad Sci 2004; 1033: 52-66.

9. Girndt M, Sester M, Sester U, Kaul H, Köhler H. Molecular aspects of T- and B-cells in uremia. Kidney Int 2000; 59 (Suppl 78): S206-S211.

10. Eleftheriadis T, Spaia S, Patsalas S, Kortsaris A, Stavrati A, Panou E et al. Aortic stiffness in patients undergoing hemodialysis is positively related to antigen presenting cell-dependent T-lymphocyte reactivity. Ren Fail 2006; 28: 63-8.

11. Sester U, Sester M, Hauk M, Kaul H, Köhler H, Girndt M. T-cell activation follows Th1 rather than Th2 pattern in haemodialysed patients. Nephrol Dial Transplant 2000; 15: 1217-23.

12. Ramirez R, Carracedo J, Berdud I, Carretero D, Merino A, Rodríguez M et al. Microinflammation in hemodialysis is related to a preactivated subset of monocytes. Hemodial Int 2006; 10 (Suppl 1): S24-27.

13. Chen SJ, Jiang GR, Shan JP, Lu W, Huang HD, Ji G et al. Combination of maintenance hemodialysis with hemoperfusion: a safe and effective model of artificial kidney. Int J Artif Organs 2011; 34: 339-47.

14. Anders HJ, Banas B, Schlöndorff D. Signaling danger: toll-like receptors and their potential roles in kidney disease. J Am Soc Nephrol 2004; 15: 854-67.

15. Krieg AM. CpG motifs in bacterial DNA and their immune effects. Annu Rev Immunol 2002; 20: 709-60.

16. Verthelyi D, Ishii K, Gursel M, Takeshita F, Klinman DM. Human peripheral blood cells differentially recognize and respond to two distinct CPG motifs. J Immunol 2001; 166: 2372-7.

17. Rysz J, Banach M, Cialkowska-Rysz A, Stolarek R, Barylski M, Drozdz J et al. Blood serum levels of IL-2, IL-6, IL-8,TNF-alpha and IL-1 beta in patients on maintenance hemodialysis. Cell Mol Immunol 2006; 3: $151-4$.

18. Knerr K, Füth R, Hemsen P, Mohné W, Heinig A, Kleophas W et al. Chronic inflammation and hemodialysis reduce immune competence of peripheral blood leukocytes in endstage renal failure patients. Cytokine 2005; 30: 132-8. 
19. Schwedler S, Schinzel R, Vaith P, Wanner C. Inflammation and advanced glycation end products in uremia: simple coexistence, potentiation or causal relationship? Kidney Int 2001; 59 (Suppl 78): S32-S36.

20. Morena M, Cristol JP, Bosc JY, Tetta C, Forret G, Leger CL et al. Convective and diffusive losses of vitamin $\mathrm{C}$ during haemodiafiltration session: a contributive factor to oxidative stress in haemodialysis patients. Nephrol Dial Transplant 2002; 17: 422-7.

21. Mircescu G. Oxidative stress: an accomplice to uremic toxicity? J Ren Nutr 2006; 16: 194-8.

22. Miyata T, van Ypersele de Strihou C, Kurokawa K, Baynes JW. Alterations in nonenzymatic biochemistry in uremia: origin and significance of 'carbonyl stress' in long term uremic complications. Kidney Int 1999; 55: 389-99.

23. Amore A, Cirina P, Conti G, Coppo R. Role of carbonyl stress products in the pathogenesis of atherosclerosis: effects on the transcription of NFk B, COX-2 and apoptosis of endothelial cells in culture. Nephrol Dial Transplant 2000; 15: 169.

24. Ward RA. Ultrapure dialysate. Semin Dial 2004; 17: 489-97.

25. Vaziri ND, Pahl MV, Crum A, Norris K. Effect of uremia on structure and function of immune system. J Ren Nutr 2012; 22: 149-56.

26. Hauser AB, Stinghen AE, Kato S, Bucharles S, Aita C, Yuzawa Y et al. Characteristics and causes of immune dysfunction related to uremia and dialysis. Perit Dial Int 2008; 28 (Suppl 3): S183-S187.

27. Meier P, Dayer E, Ronco P, Blanc E. Dysregulation of IL-2/IL-2R system alters proliferation of early activated CD4+ $\mathrm{T}$ cell subset in patients with end-stage renal failure. Clin Nephrol 2005; 63: 8-21.
28. Meier P, Meier R, Blanc E. Influence of CD4+/CD25+ regulatory T cells on atherogenesis in patients with end-stage kidney disease. Expert Rev Cardiovasc Ther 2008; 6: 987-97.

29. Jourde-Chiche N, Dou L, Cerini C, Gnat-George F, Vanholder R, Brunet P. Protein-bound toxins--update 2009. Semin Dial 2009; 22: 334-9.

30. Sakai K, Matsuda M. Solute removal efficiency and biocompatibility of the high-performance membrane - from engineering points of view. Contrib Nephrol 2011; 173: 11-22.

31. Pedrini LA, Gmerek A, Wagner J. Efficiency of post-dilution hemodiafiltration with a high-flux $\alpha$-polysulfone dialyzer. Int J Artif Organs 2011; 34: 397-404.

32. Kim S, Oh KH, Chin HJ, Na KY, Kim YS, Chae DW et al. Effective removal of leptin via hemodiafiltration with on-line endogenous reinfusion therapy. Clin Nephrol 2009; 72: 442-8.

33. Melero-Rubio E, Párraga-Díaz M, Gómez-Sánchez MP, Pellicer-Villaescusa S, Merchán-Mayado E. Observational study on markers of cardiovascular risk in renal patient: conventional hemodialysis vs. haemofiltration online. J Ren Care 2009; 35: 201-4.

34. Hyodo T, Koutoku N. Preservation of residual renal function with HDF. Contrib Nephrol 2011; 168: 204-12.

35. Ledebo I, Blankestijn PJ. Haemodiafiltration-optimal efficiency and safety. NDT Plus 2010; 3: 8-16. 